\title{
TECHNOLOGY PEDAGOGY AND CONTENT IN WEB-BASED LANGUAGE INSTRUCTION FOR SECONDARY VOCATIONAL STUDENTS
}

\author{
Eleni Papantoniou \\ Student of Open University of Cyprus, \\ Secondary Teacher of Greek Language \& Literature, ICT trainer \\ Thanasis Hadzilacos, \\ Professor at Open University of Cyprus, \\ Faculty of Pure and Applied Sciences
}

\begin{abstract}
Students in vocational schools in Greece are less motivated and have low performance in courses demanding academic skills, like language learning with reading and writing tasks (e.g. essay writing). If they were asked, they would say that they prefer to do things rather than study or get involved in traditional classroom language activities. School cannot provide them with language materials and methodology adjusted to their needs. Language teaching and learning is an academic task-oriented subject and teachers find it extremely difficult to arise their students' interest. So, from this point of view there is a gap between need and supply. How to overcome this obstacle? Is it possible that an educational e-Learning environment applying a purpose specific e-pedagogy, will do this? An experimental teaching intervention took place in a Greek Secondary Vocational Lyceum (1st EPA.L -Epagelmatiko Lykeio of Lamia city, at 2012-13 school year) in the Greek language curriculum of 11th Grade students so as the researcher to answer the above question. In an activity based situated e-environment for agriculturists, engineers, electricians, car mechanics, students were asked to solve real life technical problems and practise their mother language skills by producing technical textual 'genres' that are likely to use as future professional craftsmen.
\end{abstract}

Keywords: Problem solving, vocational students, e-learning pedagogy, situated learning, content based language learning

\section{Introduction}

As mentioned above, the teacher-researcher decided to step to an elearning class the content and pedagogical frame of which had to be designed 
from scratch. Therefore, design and instructional maters, pedagogical strategies, effectiveness factors, students' learning needs had to be considered thoroughly if her alternative e-class meant to have a real added value in comparison to the conventional teaching and learning model.

Consistent introduction of E-learning into the learning process fosters the modern ICT introduction process and creates a good environment for the integration of learning content, learning technology, various learning process designs and professional competence (Grifoll, J., Huertas, Es., et al., 2010). E-learning referred to online learning or virtual learning has been defined as a wide set of applications and processes such as Web-based learning, computer-based learning, Virtual Classrooms (VCR) and digital collaboration (Shraim, K., \& Khlaif, Z. 2010). These are teaching and learning environments where courses are not taught in a classroom face-toface but delivered on the Internet (Cruthers, 2008). 'Distributed', 'web supported', 'web enhanced', 'web dependent', 'on line', 'distance', 'flexible' learning are also terms used to refer to e-learning, without, though, always exactly referring to the same thing. They actually may reflect different types of delivery or formal status. But, whether learning and teaching is exclusively conducted via on line classes or integrates elements from face-toface teaching, virtual learning has great advantages, such as improving access to advanced educational experiences by allowing students and teachers to participate in remote learning communities. However, in order to benefit from these advantages, both learners and teachers will need to be able to adopt a new attitude towards e-learning models (Rozgiene et al., 2008). Therefore, investigating the readiness and attitude towards these models is important for their success. Designing e-learning or, as otherwise called, online (web-based) teaching environments, requires prior in-depth research and analysis, combining the understanding of both, the technical possibilities of the Internet and the ways in which the principles of instructional design maximizes the technical possibilities of the Internet (Khan, Badrul, Huda ,2005). E-learning "is a re-conceptualization of learning that makes use of not only instructor-led pedagogy but all the flexibility that asynchronous, multi-party contribution can bring” (Andrews R., 2011).

\section{Literature Review}

The research literature on e-learning has grown significantly and there is an interesting scientific dialogue on the effectiveness and success of electronic educational technologies. Though, much of this literature focuses specifically on tertiary education and not as much has been published in fully online and blended courses in primary and secondary schools (Picciano and Seaman, 2007). Because a more than desirable number of distance learning courses fail in their early editions, even the courses that have been running 
for some time suffer the loss of a considerable percentage of students who decide not to complete their studies (Bustos-Contell, E., Labatut-Serer, G., et.al., 2013), a lot of documentation has been produced in the direction of elearning systems quality and e-pedagogy. According to Jones and Peachey (2005), one of the main reasons for the failure of e-learning courses is that they adopt a merely virtual approach, without considering the human contact that students need in their learning process.

So, talking about e-learning efficiency in Higher Education, a plethora of small or wider scale research outcomes show us that we have to consider a range of 'critical success factors' (Salem M. Hassan, 2005, Masoumi, D., 2010) influencing the quality and effectiveness of e-learning settings: learner computer anxiety, instructor attitude toward e-Learning, eLearning course flexibility, e-Learning course quality, perceived usefulness, perceived ease of use and diversity in assessments are the critical factors affecting learners' perceived satisfaction (Pei-Chen Suna, et.al., 2008). The quality of recourses needs to be framed within and guided by an understanding of the broader quality of learning activity. Subsequently, there is a set of factors: pedagogical, organizational, technical and factors contributed to learner, that must be specified (Masoumi, D., 2010). Other scholars (Roux Irene, Lazenby Karen, Lordaan Dolf, 2009) underpin the importance of giving the emphasis on the pedagogy of teaching on line (from research conducted in Pretoria University), others (Stansfield, M., Connoly Th., 2009) underline the importance of posing guiding principles for promoting best practices in virtual educational communities and others suggest the need of designing and implementing a strategic plan based on a triangle model of Technology, Organisation and Pedagogy (Sangra, Albert, Guardia, Lourdes, Fernades-Michels, Pedro, 2009).

The same concern over the efficiency of web distributed/e-learning is transferred to research papers relating to Secondary Education. Scholars from different countries, with developed or developing economies and thus varying technological experience from schools, come to similar conclusions: the secondary students of a state US school attending an e-history course (Wayne Journell, 2010) maintained a belief that e-learning was best used for information transmission and rote memorization rather than active or social learning, whereas the Palestinian school students attending the Alaws Educational Network (a platform that provided a variety of methods for a student-centred learning process including Virtual Classrooms (VCR), discussion forum and e-training courses) 'showed positive attitude towards the usefulness of e-learning methods but they were maybe not yet ready to adapt them' (Shraim, K., \& Khlaif, Z., 2010). Although the research in the field of e-learning effectiveness in the secondary, K-12 stage education is limited and provide only limited insight into the complexities of the theme, 
one thing that emerges is that the effectiveness of distance education appears to have more to do with who is teaching, who is learning, and how that learning is accomplished, and less to do with the medium. This question of students' support effectiveness is especially critical when considering the alternative nature of the educational experience and the proclivity for its attractiveness to at-risk student populations (Rice, Lynn Kerry, 2006).

The pedagogical framework represents an essential part of the elearning system conceptualization and development and offers sound concepts for the development of learning scenarios in order to enhance the learning experience of students in secondary schools. According to the UNITE Europe-wide project1, this framework is composed of the pedagogical approaches, assessment techniques, teacher education and national specifics and current pedagogical practices implemented in national curricula. Often, on line pedagogical practices are restricted by school contexts, organizational structures and established mechanisms of control in schools, such as national curricula and assessment systems. The effective use of new technologies requires an organized pedagogical structure so that students can develop their own meaningful representations of knowledge using e-Learning. But in order teachers to adopt strategies facilitating learning, they can provide structured and focused classroom tasks (Granić, A., Mifsud, C., \& Ćukušić, M., 2009). At this point we can only bring to mind the excellent work of Salmon's (2002) research which provides a solid foundation for relevant and purposeful online instructional activities ('etivities'2). The Five-Step Model offers an excellent paradigm for combining

\footnotetext{
${ }^{1}$ 'Within the context of a Europe-wide project UNITE, a number of European partners set out to design, implement and validate a pedagogical framework (PF) for e- and m-Learning in secondary schools. The process of formulating and testing the PF was an evolutionary one that reflected the experiences and skills of the various European partners and secondary schools involved in the project. The framework involved pedagogies which underpin the teaching of subject matter in a number of European secondary schools as well as the ways in which learning is delivered and assessed'. More information in the article: Design, implementation and validation of a Europe-wide pedagogical framework for e-Learning ResearchGate. on:

http://www.researchgate.net/publication/223529298_Design_implementation_and_validatio n_of_a_Europe-wide_pedagogical_framework_for_e-Learning [accessed Jul 16, 2015].

2 Characteristics of E-tivities : It is important that online instructors have the appropriate educational resources to individualize their lesson plans and course materials for their classes. Salmon (2002) provides a host of educational resources (i.e. scenarios, ideas for reflective dialog and professional development activities) in E-tivities: The key to active online learning that can used by instructors in their classes. The e-tivities are designed to engage online students in meaningful work that captures their imagination and challenges them to grow. There are five vital features to e-tivities: 1 . A small piece of information, stimulus or challenge (the 'spark'), 2. Online activity which includes individual participating posting a contribution, 3 . An interactive or participative element-such as responding to the
} 
theory and practice into the teaching and learning process by sharing meaningful activities in a learner-centered environment.

The study of international research in this field yielded interesting results, although I found that little research evaluating the effectiveness and successful outcomes for students using technology, especially in the vocational school sector, has been undertaken. The adoption by the trainee of a new learning style, in which a high degree of awareness of learning requirements and high metacognitive skills ( that is the student / trainee knows how to learn and how to interact with educational material) appear to be essential part, is not an easy nor obvious case in web-based distance learning. And this is a basic reason why 'today online learning is primarily used in a blended learning environment in which the students learn through a combination of online learning system, hands-on activities and classroom teaching in the vocational college' (Cigdam, Harun, Yildirim, Osman Gazi, 2014).

However, wherever such E-learning policies in vocational school sector took place, the results were encouraging as far as the students efficiency and retention rates level is concerned. For instance, in the context of the Australian VETiS (VET in Schools) program, e-learning had a largely positive impact on the student's skill and confidence in technology and has prepared them very well for workplaces beyond school. E-Learning has also improved their method and medium of communication, helped in activities which focused on teamwork and assisted them to be organised. E-learning tools supported students in developing these employability skills and enhanced their work readiness for employment after Year 12 (Ryan, Katherine, 2014). Also, in another country, Taiwan, a Web-Enabled Problem-Based Learning and Self-Regulated (SRL) Learning was undertaken by teachers-researchers in order to enhance computing skills of Taiwan's Vocational Students. SRL was applied to help vocational students in Taiwan to concentrate on their learning, practice their schoolwork, and furthermore, take responsibility for their learning. According to the study, results were generally positive, showing enhanced student computing skills (Pei-Di Shen, Tsang-Hsiung Lee, Chia-Wen Tsai, 2007).

In relation to the Greek Secondary Vocational -Technical Education, the availability of online courses to produce an asynchronous distance teacher-student collaboration, is not a widespread regular schools strategy and there are not many innovative teaching interventions that attempt to introduce a more consistent and systematic adoption of E-learning education

postings of others, 4. Summary, feedback or critique from an e-moderator (the 'plenary') 5. All the instructions to take part are available in one online message (the 'invitation') (based on the Book Review of 'E-tivities: The key to active online learning' by Brent Muirhead (on line: http://www.ifets.info/journals/5_4/muirhead_book_review.html) 
in everyday teaching and student practices. Additionally, the majority of such small scale e-learning teaching projects are conducted by teachers of Informatics. However, the important thing is that at the end of such pilot educational programs the researchers come to similar conclusions. They underpin the need for the development of teaching electronic learning systems to enhance, update and enrich the technological courses taught in vocational secondary and postsecondary educational institutions in the country, so that students and professionals to amplify their knowledge and develop new skills and business activities (Siafis, Bissarion 2012).

\section{Moving to an E-learning language instruction for Secondary Vocational Students}

\section{The problem to be treated}

Students in vocational schools in Greece are less motivated. They come from educationally poor backgrounds and, thus, develop poor school progress. Among their low performance characteristics, as far as language competency is concerned, they have increased difficulty in reading comprehension and writing skills. They generally show a negative attitude towards general education courses, such as language learning and maths, in which they present very low scores compared with their General Education Lyceums peers. From my personal long experience as a vocational language teacher in Greek EPA.Ls and according to other colleagues-researchers' findings (Ploumidou, 2002, Rapti, Katsanou 2003, Papaleonida, P., Bechrakis, Th., 2007, Hatzisavvidis, S., 1993), vocational students find small or null interest in academic courses as they find them more difficult and poorly connected with real life or their work interests. 'Students show no special interest in general education classes, judging by the rating in the respective subjects, ...Here we can assume knowledge gaps or negative experiences. They appear to show higher interest in the specialty they have chosen. In some cases they even show exceptional performance' (Ploumidou, 2002). Generally speaking, vocational students prefer to do things and not to learn in the traditional course settings including face to face lecture, academic tasks and homework. They do not seek the optimum learning outcome, because they feel they do not need it in the 'outside' labor market. They do not have high educational goals after finishing school, as most are not interested in university departments, but they have immediate need or desire to work quickly. They want "to get a 'paper' (diploma or degree) so as to quickly get integrated into the labor market, or to 'see what they will do'" (Pangalos, 2005). "All I ask and will ask you too to be done is when I finish school to get a job because our parents cannot sustain us forever ..." (Ministry of Education \& Religious Affairs, 2011). Students show more interest in acquiring technical skills and practical knowledge related to 
specific professions and job sectors, rather than academic knowledge, knowledge that enhance thinking and logic. Often they devalue the teaching of language, history, mathematics and other general education courses, as they do not easily distinguish the connection to real life. Indeed, as shown by a recent survey (Ministry of Education \& Religious Affairs, 2011), the basic specialty selection criteria are mainly related to students' interests and their employability after school, while $30 \%$ of students of secondary Vocational Education find it extremely difficult and $47 \%$ very difficult to attend theoretical courses.

Despite being native speakers of the Greek language, they do not have an excellent or very good command of the language. As far as their speech and writing ability more specifically, Greek vocational students show increased difficulty in presenting their ideas and arguments in written form successfully. As written texts obey to various composing contracts that differentiate them from the spoken word (as to spelling, vocabulary, syntax, meaning making, textual organization) and contracts related to the genre in which the produced text belongs, students attending EPA.L are unable to write with sufficient reasoning, documentation, analysis, description. They often do spelling mistakes, they give poor texts, with little information inside, often badly structured. Their written texts lack in size, have poor content, few arguments, texts are not complete with a beginning, middle and end (Papanastasiou, 2012, Rapti, Katsanou 2007).

Despite all this situation, Greek vocational lyceums have got language courseware taken from the General Lyceums, that is, vocational students are taught according to language curriculum for general and academic purposes. The school cannot provide them with language materials adjusted to their needs. Language teaching and learning is an academic task oriented subject and teachers find it extremely difficult to arise their students' interest. So, there is a gap between need and supply. The teacher, in order to fill this gap has to recreate her lessons and adjust them to her real students' expectations. So, the researcher thought that it would be more meaningful and appealing to the students if they were taught how to improve their mother language skills so as to communicate efficiently with future customers, to present business/technical information, explain problems, write and form attractive financial offers through internet, advertise their business, make accurate technical reports e.t.c. So, somehow the bet for the teacher was to transform academic language learning to a purposeful, subject specific language learning by utilizing technological potentials for constructing e-environments simulating job communities and work settings. Of course, that was not as easy, as the experimental group had no previous e-learning experience and they had not previously been taught 
how to write technical genres: they were not familiar with technical writing and 'genres' pedagogy practices.

\section{The students' profile}

As an Action Research practitioner, I put my alternative teaching model into a test treatment. Any change in the experimental group's performance and attitude would be identified by comparing a pre-test and post-test qualitative data coming from the same group as well as from a second control group by following a true experimental research design. Special evaluation criteria were set for the test conducted throughout the 6month period of the experiment and the results emerged from the final data comparison and assessment were quite interesting and encouraging. Before that, though, in order to better prepare and apply my language instructional program, I collected data concerning my students learning profile drawn from a variety of methodological tools, as a questionnaire, a diagnostic pretest, by personal observation and by consulting my colleagues who had worked with the same students the previous school year. 'By doing so, the instructor will be able to offer the most appropriate courses to suit the students' needs and levels, and eventually achieve the best teaching and learning results' (Su, M. H. M. (2005). In short, my students:

- had not all the same level of digital literacy. Although in the previous year class (10th) they had attended Informatics course, very few had a strong technological capacity in terms of handling digital data and operating things in various software environments. Instead, all of them were familiarized with social media as they had a Facebook account and used social media to interact with other teenagers, to upload files and share digital material. Additionally, as most students of their age used mobiles and smartphones, played electronic games and knew how to surf in the entertaining web paths.

- $43 \%$ of the students from the control group and $50 \%$ from the experimental group worked alongside their schooling, $20 \%$ of the students from the control group and 23\% from the experimental group had officially diagnosed learning disabilities and presented mild delinquency. 50\% of the students from the control group and 59\% from the experimental group had no personal access to the internet (via personal mobile, P.C, tablet).

- as all 11th grade EPA.L/Vocational students in Greece, they were separated to professional specialties (sectors). In my two groups there were car mechanics, electricians, agriculturists and engineers exercising the respective technical skills.

- the students of the experimental group showed worse performance in comparison to the control group. At the pre-test examination conducted in the school at the beginning of the project, the first group failed (scored under 
the passing level) at 77\%, whereas the second group failed at $67 \%$. Additionally, 63\% of the experiment group preferred not to answer the writing task of the test at all (the control group at 33\%).

- in the process, the students of the experimental group quickly revealed their weakness to be self regulated: they had metacognitive difficulties, as they could not understand the written instructions, they asked for help or further explanations, they lacked knowledge of grammaticalsyntactic terms (e.g what 2nd verb person is, how to turn from passive to active voice e.t.c.), they did not know to interact with the given resources and handle them in a critical, appropriate manner according to the problem's demands.

\section{Adjusting e-pedagogy to Language Instruction: choosing the right pedagogy}

An e-Learning system design based on selected pedagogical model enables teachers to make use of the learning resources in a form which is appropriate to the learning goals and the particular learning style of the student (Granić, et al 2009). Although research has shown a considerable number of positive outcomes of the use of ICT within the classroom setting, Hayes (2007) points out that the integration of ICT is highly dependent on the teachers who have to master these new tools and to reach their teaching objectives through their use.

Mother language competency is mainly important for these students in order to communicate in their work area, to understand texts related to technical issues (for example manuals usually written in formal Greek), to explain problems adequately and, generally, to keep a lifelong awareness and knowledge ability. Although the course content was subject specific, language use had a further value for the mother language improvement, as the main linguistic functions were activated in writing activities so as to produce narrative, argumentative, descriptive advisory texts. In this framework, suitability of words and syntax, accuracy, coherency, communicational effectiveness, critical thinking, topic analysis and solution's presentation were checked.

For the creation of a subject specific courseware the researcher needed the right input and strategy. Input refers to the spoken, written and visual data that learners work with in the course for the completion of a task. It relates to authenticity and in this context refers to the use of spoken and written material that has been produced for language teaching purposes (Reni, N. 2012). As for the strategy, the problem solving approach was chosen with regular technical problem supply by which a sequence of problems were posed to each vocational group to be solved. 
The experience reported in the relative research field of Content Based Instruction and Problem Based Learning, although applied most in second language acquisition, was very encouraging especially when referring to vocational secondary education. Content Based Learning makes an assumption that learners learn best when they are given language in a meaningful, contextualized form, that is language is associated with useful information, so CBL is more motivating as the learner focuses on something else, such as ideas, opinions, issues and not on the language itself (Coelho, El. 2004). In relation to the English courses in vocational schools, Reni notices something important: The curriculum in a vocational high school gives the information about the teaching learning process that occur in vocational high school. The aim of vocational schools is providing the students for the work area. It should be more specific than senior high schools. For that reason, students of a vocational schools need English for Specific Purposes ${ }^{3}$ to provide the next step for getting the job (Reni, N. 2012). ESP is best acquired through the subject matter basically due to learners' genuine interest in it. Subject matters can be introduced by English language teachers throughout English classes by employing vocational materials. All these stages employ learners' professional knowledge and prompt them to activate it in a foreign language (Kavaliauskiene, Galina 2004).

As it is clear, the above conclusions apply in curriculum areas concerning second language acquisition, whereas the present study focuses on the 'language for specific purpose' approach as a method for mother (Greek) language use improvement in vocational schools. So the researcher tried to educate her students to use Greek language purposefully in texts written for specific reason in a certain social/communicational framework. Students were provided with multimodal, supportive resources (charts, pictures, photos, videos, webpages, lists e.t.c) and critically chose the right elements to complete their e-activities. The Problem Based Learning approach was considered to be the crucial factor that motivated students to be engaged in the e- writing activities. The teacher-researcher tried to realize a transmission not just from a real classroom settings to an e-classroom environment, but to transform methodology as well, from language centered, academic classroom activities to Problem Based language e-activities connected to authentic, problematic situations in real work conditions. This last element somehow attributed the experimental project the character of a

\footnotetext{
${ }^{3}$ English for Specific Purposes: the term is described in Hutchinson, T., \& Waters, A. English for specific purposes (1987, Cambridge University Press) as an approach to language teaching in which all decisions as to content and method are based on the learners "reason for learning". In other words, ESP is an approach to language learning which is based on learners needs.
} 
Situated Learning based application. Most modern Situated Learning approaches put the emphasis on the concept of forming the learning-social identity as people negotiate meanings through interactions within communities of practice. These optics of S.L were widely adopted in education, in instructional design, in online communities and artificial intelligence systems (Clancey 1993). As far as language teaching is concerned, a natural relation between S.L and New Literacy has been recognized (Gee, 2010), as in S.L students learn through experiences. These experiences are acquired gradually through tools, technology and language varieties used by a socio-cultural group of people and the way the group gives meaning to these instruments. Thus, in S.L. people are more energetic at what they do and literacy practices have meaningful content as they are embedded in broader social goals and cultural practices. Of course, the present teaching intervention did not formally met all the conditions for having a S.L. as defined above, since: a) students were not apprenticed in real workshops, but in virtual workplaces, b) interaction has not worked so between them, as with educational material and electronic support and c) the teacher-researcher, as a Greek language teacher, was not 'special' in the technical aspects of activities, but partially substituted that role supplemented mostly by educational materials. For the purposes of the research, however, she studied various curriculum material of the Vocational Sectors and cooperated with colleagues-specialists.

\section{The key features of the e-learning activities}

Already from the analysis phase of the project, I realized that I had to design and develop a web based application concentrating the following ten technical and pedagogical prerequisites so as to better meet my students' real needs. The e-course had to be:

1. multimodal by representing information via an attractive variety of audiovisual semiotic recourses(text, image, photos, video, e.t.c). Students had openly expressed their dislike to reading and studying long texts (single, word printed material), whereas at the same time were strongly attracted by audiovisual applications and devices. So, it emerged as a strong need for the researcher to utilize not only verbal (single-mode) material, but multimodal courseware to support the e-activities and tasks in an effort to make the eenvironment and study ware more attractive, pleasant and motivating for students of reduced school performance. Besides, research literature for multimodality is rich and has proved the beneficial linkage between multimodality and modern learning practices. Kress (2003) explores the connection between multimodality and learning (not only e-learning), suggesting that transformation is a key concept in a theory of meaning, 
concerning how users re-shape meaning according to the available resources (also in Andrews R., 2011).

2. a social media like, easy to use, interactive platform. Regardless of their true digital literacy, all students were Facebook users. So it was obvious to the researcher that a social networking environment with the characteristics of Facebook, safe though and within delimited educational communities, would be an attractive medium for school practice. Among a series of educational Learning Management Systems, Edmodo was finally chosen for the application mainly because of its low technical complexity, operating adequacy and user-friendly interface. The teacher/administrator registered the students as Vocational group members (the electricians, the agriculturists..) and delivered different technical problems and accompanying multimodal resources for each group.

3. accompanied by gradually decreasing guidance and instruction. Another key pedagogical strategy is that of clear guidance through which students systematically and clearly understand how to get on with the input, what to do with the activity structures and meanings, thus developing metacognitive skills. The factors that determine the complexity of what learners have to do are relevance, complexity, amount of context provided prior to the task, possibility of language of the task, amount of help available to the learner (Nunan, 2004). And guidance refers to all above. As an instructor and mentor, the researcher had to answer students' questions concerning clarification on the requirements of the problems posed each time and the way they had to build their technical writing, but also she had to help her students with the professional roles they had to act out in order to adopt an appropriate writing style and give the appropriate form to the requested technical 'genres'. Students, although being trained in various crafts (by theory and laboratory lessons), were found not to be familiar with social practices and communication skills of the real job fields, so the instructor-researcher had to assist them get familiarized to a variety of communicative situations and the linguistic requirements each time.

4. transformative as transforming the way students studied, learned and interacted with the educational material through a highly-demanding, rich pedagogical environment and a multi-combined teaching methodology. When designing e-Learning systems it is important to have a clear understanding of the planned pedagogical objectives as well as to decide on which pedagogical approach is to be employed. In this case the introduction of an alternative pedagogical approach basically constituted a combination (a set) of pedagogical principles and strategies: technical problem solving, situated learning features, explorative learning with decreasing guidance, content-based language learning, pedagogy of 'genres', multimodal teaching material database, constructive learning. All these skills and strategies were 
activated actually around a core topic problem to be solved, as students had to identify the problem, reflect on it, comprehend technical functions, find the missing information, recover old knowledge, critically combine various pieces of information, find out reasonable answers-solutions and finally write correctly.

5. subject specific with problem-based language activities immediately connected to the technical curriculum of the Vocational Lyceums (EPA.l): subjects taught in the Vehicles, Electrical, Agriculture and Engineering sectors, the sectors the students attended.

6. outside world relevant, job connected as in Edmodo's platform the students were separated in work groups and had to behave as in a real professional electronic forum-community with the corresponding multimedia recourses, content, answers and discussions focused on certain authentic problematic conditions situations. Students simulated professional technicians and thus slightly developed a specific type of social behavior and discourse. As Anderson, Greeno, Reder and Simon highlight (2000), situated learning approaches focus on coordination of trainees' actions among themselves and with the materials and information systems and, in that sense, learning is like a process of participatory routes which actively promote community operations and literate identities.

7. familiar and confidence giving, as students had to be helped feel at ease with content relating more to their own culture and interests and with materials helping them to easily cope with the technical problems and not feel as being tested and evaluated. Regular and immediate feedback had a crucial role in encouraging students keeping up with the activities and trying for the best each time.

8. highly motivating so as to make students get involved and try out their capacity. For that reason, the problems delivered on the platform every week had to be appealing and interesting: from different experience area each time, unexpected so as to break the monotony, with topics of interest to the target group or topics which offer the possibility of learning something new.

9. focused on certain specific things to do and with not excessive information provision, but enough so as the student can find the necessary information in it. Otherwise, problem-based tasks could deter students from getting involved to solve them.

10. based on a blended e-learning model. Moving to an e-learning, LMS based educational environment is not a natural thing to happen for vocational students who had never before worked in this way at school. The teacher-researcher had to take into consideration how much ready her students were for that and their own self regulating pace. The model of 'blended learning', in which the distance learning should work combined with 
"face to face" training, was utilized for that reason: to fill the gradual transition from the familiar 'face to face' teaching to an exclusively assisted by computer teaching and learning. Although the researcher had first demonstrated to the experimental students the way the platform worked and how the e-course project would function, they initially showed so little confidence in dealing with the e-activities, that the she and her students was arranged to meet in the school P/C laboratory once a week for support giving and physical interaction.

\section{The e-activity procedure through a Technical Problem Based Example}

In order to clarify the way the language instruction is structured and works in this subject specific language course, I am quoting an example from the Car Mechanics Group.

The problem as it was delivered on the e-platform

\section{Make a personalised offer for changing car tires - to be submitted january 17, 2013}

The SCENARIO: You are a car workshop owner. Two clients whose car tires need changing ask you to make the best offer for their special case:

1) the first customer lives in Northern Greece in an area with low temperatures for several months a year. He mostly moves in hilly country roads. He has a 2006 DAIHATSU TERIOS II model.

2) the second customer lives in South Greece (city of Kalamata), a region with high average temperatures, he usually travels on the region's streets and avenues and in the national road network. He has a 2010 Suzuki Swift model.

NOTE: In order to suggest the right tire choice, you should take into account the following things: the size and type of the vehicle, usual weather driving conditions, car driver's behavior and everything else necessary.

WRITING INSTRUCTIONS Write a documented suggestion for each client and the appropriate offer (one per customer). So, in your text you should a) propose specific kind and type of tire b) justify your choice (based on your customers' needs) c) indicate the technical characteristics of the appropriate tires and d) state the price details for each tire purchase as well as for all the labor and service work.

Attached digital RESOURCES

1. The new European Tire Labelling webpage (http://www.michelin.gr/tyres/learn-share/buying-guide/new-tyregrades)

2. Tire searching website (http://www.elastika-online.gr/)

3. Winter tires/safe driving (webpage and video on http://www.safedriver.gr/ index.php?productID=16\&ckattempt=1 ) 
4. An e-auto journal titled 'The types of tires'

5. The michelin.gr website

Basically, as far as the students effort is concerned, the e-activity consists of two parts: a) finding the solution to the technical problem b) writing the text-the relevant technical 'genre' . So:

\section{Trying to find the solution, the students}

1. identify the technical problem - in the specific example they must find out types of tires appropriate for each car model in combination with the weather and driving conditions. They highlight the key features of each driver.

2. make a general assumption about the right type of tires, but in order to form a more precise knowledge on the topic, they seek for the missing information in the given digital resources.

3. search and find the technical characteristics fitting in each case. Additionally, because they have to make a financially attractive offer, they also seek for the best prices offered for each tire type and end up with precise tire model suggestions.

4. type the selected information in notes so as to be able to form a complete answer

\section{Trying to write a personalized offer for each customer, the students:}

5. Are given a model standard offer made for a different product (soil water heaters, agricultural vehicle, insulating technique etc).

6. Under the guidance of the instructor, identify the communicative purpose, the key words, features and structure of the standard text-genre

7. Then, try to tailor the specific, tire related information findings to the genre's characteristics. In this case, they have to write an appropriate title, shortly and reasonably support the certain choice, give a technical description of the specific product, underpin the advantages, state the suggested price in details, possible payment facilities, communication information etc

8. post/publish their final offer

9. take immediate feedback

10. review and rewrite their offer if needed

\section{Conclusion}

The pedagogical formula that was built in the triangle of TechnologyPedagogy-Content proved to be fruitful in the case of these 11thgrade vocational students, as it incorporated interesting, learner-centered content, challenging activities, e-learning tools. The language course became suddenly not as boring as in their previous classroom experience and this increased their actual participation in problem solving writing tasks. Although, by the 
researcher's side, there was no persistence in producing morphologically flawless technical texts (especially in spelling), the students of the experimental group enhanced significantly their skills in developing technical document types: commercial offers, brochures, promotion services through professional website, technical advice, documented technical problem reasoning, demonstration techniques in an apprenticeship or video e.t.c. This progress was recorded as to level of quantity (text area), linguistic level (use of vocabulary, structure, grammatical-syntactical elements), communicativesocial level (understanding communicative objective, adopting socialprofessional roles, adopting a similar style and linguistic diversity) and critical-quality or metacognitive level (understanding the subject requirements, adoption of text development strategies, management and editing of educational materials and sources, critical selection of information). The connection to the real business world helped the students to increase their internal motivation to be engaged in speech production as a part of a wider professional attitude and behavior. The contextualized learning environment strengthened their professional identity and the emerging literacy.

\section{References:}

Anderson, John R., Greeno James G., Reder M. Lynne, Simon A. Herbert (2000).

Perspectives on Learning, Thinking, and Activity. Educational Researcher, 29 (4), 11-13.

Andrews, R. (2011). Does e-learning require a new theory of learning? Some initial thoughts.

Journal for Educational Research Online, 3(1), 104-121.

E. Bustos-Contell, G. Labatut-Serer, J. Martínez-Vargas (2013). KEYS TO AVOIDINGFAILURE ON E-LEARNING COURSES, EDULEARN13 Proceedings, pp. 707-712.

Cigdem, H., Yildirim, O. (2014). Effects of Students' Characteristics on Online Learning Readiness: A Vocational College Example. Turkish Online Journal of Distance Education, 15 (3), 80-93. Viewed 06 Sept. 2015, http://dergipark.ulakbim.gov.tr/tojde/article/view/5000102131

Clancey, W. J (1993). Situated action: A neuropsychological interpretation response to Vera and Simon. Cognitive Science, 17, 87-116. Viewed 10 Sept. 2015 :

http://www.cs.ucf.edu/ lboloni/Teaching/EEL6938_2007/papers/Clancey-

Situated- Action-Neuro-Interpretation.pdf

Coelho, E. (2004). Organizing language Instruction. In Adding English: A Guide to Teachingin Multilingual Classrooms. Pippin Publishing Corporation. Retrieved from: 
https://books.google.gr/books?hl=el\&lr=\&id=_RDWv9QBJc0C\&oi=fnd\&pg $=$ PA9\&dq

$=$ Coelho, + E. $+(2004) .+$ Organizing + language + Instruction\&ots=WxjAejmrM Q\&sig=Q213ahXagHXw1o2VChfeM-

jMHLM\&redir_esc $=\mathrm{y} \# \mathrm{v}=$ onepage $\& \mathrm{q} \& \mathrm{f}=$ false

Cruthers, M. (2008). Education Technology Gives Teachers a Wider Reach. ETNI, 5.

Retrieved from: http://www.etni.org.il/etnirag/issue5/mark_cruthers.htm

Granić, A., Mifsud, C., \& Ćukušić, M. (2009). Design, implementation and validation of a Europe-wide pedagogical framework for e-

learning. Computers \& Education, 53(4),1052-1081.

Grifoll J., Huerta E., Prades A., Rodríguez S., Rubin Yuri, Mulder F., Ossiannilsson E.

(2010). Quality Assurance of E-learning. ENQUA Workshop report, 14.

Helsinki. Retrieved from: http://www.enqa.eu/indirme/papers-and-

reports/workshop-and-seminar

/ ENQA_wr_14.pdf

Hatzisavvidis, S. (1993). Investigation of the factors affecting the level of language proficiency of students in the school environment: First estimates of a "Case Study"'.

Proceedings of the 14th Annual Meeting of the Linguistics Faculty of Philosophy, 384.

Retrieved from: http://www.komvos.edu.gr/glwssa/dokimes/

TANIS/xatzisabidis.htm

Hayes N.A. Debra (2007). ICT and learning: Lessons from Australian classrooms.

Computers and Education, 49 (2), 385-395. Retrieved fromhttp://dx.doi.org/10.1016/ j.compedu.2005.09.003

Jones, N. \& Peachey, P. (2005). The Development of Socialization in an onLine LearningEnvironment. Journal of Interactive Online Learning, 3(3), 120.

Kavaliauskienè, G. (2004). Research into the Integration of Content-Based Instruction into the ESP Classroom. Journal of Language and Learning, 2(1).

Khan, H.B. (2005). Managing E-learning Strategies: Design, Delivery, Implementation and Evaluation. Information Sciense Publishing. Retrieved from:

https://books.google.gr/books?id=WVL9ix9EZskC\&printsec=frontcover\&hl $=$ el\&source $=$ gbs_ge_summary_r\&cad $=0 \# \mathrm{v}=$ onepage \&q\&f=false

Kress, G. (2003). Literacy in the media age. London: Routledge. 
Kruse, Kevin (2004). Introduction to Instructional Design and the ADDIE Model. In Transformative Designs website. Retrieved from:

http://www.transformativedesigns.com/

Masoumi, D. (2010). Critical factors for effective eLearning. Goteburg University.

Ministry of Education \& Religious Affairs (2011). Presentation of the current situation in EPAL-EPAS with the development and use of ICT tools in the application of educational policies and interventions of the Ministry of Education, Lifelong Learning and Religious Affairs. Education and Lifelong Learning 2007-2013 Development Project.

Nunan, D. (2004). Task Based Language Teaching. A comprehensively revised edition of Designing Tasks for the communicative classroom. Cambridge University Press.

Pangalos, St. (2005). The New Structure of Secondary Technical Education . Design Criteria, requirements, suggestions. Engineers and Secondary Education workshop paper, 15-16,

Athens. Retrieved from:

http://portal.tee.gr/portal/page/portal/SCIENTIFIC_WORK/EKDILOSEIS_P /EPISTHMONIKES_EVENTS/DEYTEROVATHMIA\%20EKPAIDEYSH/ 199/5.pagalos\%20omilia.pdf

Papaleonida, P., Bechrakis, Th. (2007). The Social Characteristics of students attendingInformatics in Vocational Training. Proceedings of the 20th Panhellenic Statistics Conference Greek Statistical Institute, 321-328. Papanastasiou, A. (2012). Teaching the supportive course of Greek Language in A' Class of Technical Lyceum with ICT. A first assessment of the new reality. Proceedings of the Education in the Age of ICT Conference. Sun, P. C., Tsai, R. J., Finger, G., Chen, Y. Y., \& Yeh, D. (2008). What drives a successful e-Learning? An empirical investigation of the critical factors influencing learner satisfaction. Computers \& education, 50 (4), 1183-1202.

Shen, P.D., Lee, T.H., Tsai C.W. (2007). Applying Web-Enabled ProblemBased Learning and Self-Regulated Learning to Enhance Computing Skills of Taiwan's Vocational Students: a Quasi-Experimental Study of a ShortTerm Module. Electronic Journal of e-Learning, 5 (2), 147 - 156.

Picciano, A. and Seaman, J. (2007). K-12 Online Learning: A survey of U.S. SchoolDistrict Administrators. Sloan-C. Retrieved from:

http://www.onlinelearningsurvey.com/ reports/k-12-online-learning.pdf Ploumidou, P. (2002). Geographic origin and social profile of students of TechnicalVocational Schools (TEE) - Case study: Municipality of Halandri. Halandri Municipality's influence zone of TEE in relation to the spatial distribution. Thesis. Retrieved from: http://courses.arch.ntua.gr/el/gevgrafikes_dynamikes_kai_sygxronoi_ 
metasxhmatismoi_toy_ellhnikoy_xvroy/diplvmatikes_ergasies__periliceis.html

Rapti M., Katsanou M. (2007). The linguistic ability of students of General and Vocational Lyceum. Proceedings of the Second Educational Conference 'Language, Thinking and Action in Education. Ioannina. Retrieved from: http://ipeir.pde.sch.gr/educonf/2/defterovathmia_ekpethefsi.html Reni, N. (2012). DESIGNING ENGLISH LEARNING MATERIALS FOR GRADE TEN STUDENTS OF INFORMATICS TECHNOLOGY PROGRAM AT SMKN 1PAJANGAN BASED ON THE SCHOOL-BASED CURRICULUM IN THE ACADEMIC YEAR OF 2011/2012. Doctoral dissertation. Retrieved from: http://eprints.uny.ac.id/9448/

Rice, K. L. (2006). A Comprehensive Look at Distance Education in the K12 Context.

Journal of Research on Technology in Education, 38 (4), 425-448. Retrieved from: http://eric.ed.gov/?id=EJ768723

Roux I., Lazenby K., Lordaan D. (2009). Advancing Elearning Policies. E learning andVirtual Campus Development. In Institutional Transformation through Best Practices in Virtual Campus Development. Information Science Reference. Retrieved from: https://books.google.gr

Rozgiene, I., Medvedeva, O., Straková, Z. (2008). Integrating ICT into Language Learning and Teaching: Guide for Tutors. Retrieved April 10, 2015, from:

https://www.academia.edu/2454849/Integrating_ICT_into_Language_Learni ng_and_Teaching

Ryan, K. (2014). Outcomes of incorporating e-learning in school VET delivery: How has Gen Y benefited from the 1:1 laptop program? Proceedings of AVETRA Conference.

Retrieved June 20, 2015, from: http://avetra.org.au/wp-content/ uploads/2014/05/Abstract-111.pdf

Salem H. M. (2005). Critical success factors for elearning acceptance: Confirmatory factor models. Computers \& Education, 49, 396-413.

Salmon, G. (2002). E-tivities: The key to active online learning, London: Kogan Page.Sangra, A., Guardia, L., Fernades-Michels, P. (2009). Matching Technology, Organisation and Pedagogy in E-learning: looking for the Appropriate Balance Leading to

Sustainability and Effectiveness. In Institutional Transformation through Best Practices in Virtual Campus Development: Advancing elearning policies. Information Science

Reference. Retrieved from: books.google.gr

Shraim, K. \& Khlaif, Z. (2010). Students' Readiness Towards E-learning. A case study of Virtual Classrooms for secondary education in Palestine. 
Proceedings of The 3rd Annual Forum on e-learning Excellence in the Middle East. Dubai.

Siafis, V. (2012). Design and Development of e-learning environment for PLC (Programming

Logical Controllers - PLCs). Master Thesis from the Digital Resource database of Open University of Cyprus, Kipseli.

Stansfield, M., Connoly Th. (2009). Guiding principles for Identifying and Promoting Best Practice in Virtual Campus. In Institutional Transformation through Best Practices in Virtual Campus Development: Advancing elearning policie'. Information Science

Reference. Retrieved from: books.google.gr.

Su, M. H. M. (2005). A study of EFL technological and vocational college students' language learning strategies and their self-perceived English proficiency. Electronic Journal of Foreign Language Teaching, 2(1), 44-56. Wayne, J. (2010). Perceptions of e-learning in secondary education: a viable alternative to classroom instruction or a way to bypass engaged learning? Educational Media International, 47(1), 69-81. 